\title{
The TrkB agonist 7,8-dihydroxyflavone improves sensory-motor performance and reduces lipid peroxidation in old mice
}

\author{
Hatice Keser ${ }^{1}$, Şeniz Doğramacr², Elif Şahin², Neslihan Sağlam² ${ }^{2}$, Mehmet Erdem², Ahmet Alver² \\ and Selcen Aydın-Abidin ${ }^{1}$
}

${ }^{1}$ Department of Biophysics, Faculty of Medicine, Karadeniz Technical University, Trabzon, Turkey

${ }^{2}$ Department of Medical Biochemistry, Faculty of Medicine, Karadeniz Technical University, Trabzon, Turkey

\begin{abstract}
Dihydroxyflavone (7,8-DHF) is a natural flavonoid compound that act as Trk-B agonist. 7,8-DHF is also a potent antioxidant. When applied systematically, 7,8-DHF can pass through bloodbrain barrier and exhibit potential therapeutic effects in several animal models of neurodegenerative disorders. This study investigates the remedial effects of 7,8-DHF on behavioral impairments and biochemical changes associated with aging with a species emphasis on cortex. For this purpose three experimental groups were formed which are young control group, old group and old-DHF groups. $5 \mathrm{mg} / \mathrm{kg}$ 7,8-DHF was administered intraperitoneally to old-DHF group for 3 weeks. We assessed the hang wire and adhesive removal performances of mice. Also, oxidative stress, neuroinflammation and synaptic protein levels in the cortex were measured. We observed that chronic administration of 7,8-DHF improved behavioral performance of old mice. Besides, 7,8-DHF reversed MDA level which was increased in old control animals. However, 3 weeks application of 7,8-DHF failed to recover the levels of neuroinflammation markers (TNF- $\alpha$ and IL-6) and synaptic proteins (PSD-95 and Synaptophysin) which were reduced in old group. These findings demonstrate that improvement of age-dependent behavioral impairments and MDA levels by 7,8-DHF could be attributed to its antioxidant actions.
\end{abstract}

Key words: Aging - 7,8-Dihydroxyflavone - Oxidative stress - Synaptic proteins - Mice cortex

\section{Introduction}

Aging is a physiological process and in aging brain neuroinflammation and oxidative stress increases, synaptic structures and overall functions are disrupted (Bao et al. 2014). Brain aging is shown to be a natural predisposition for some neurodegenerative disorders such as Alzheimer's and Parkinson's diseases (Keller 2006; Lin and Beal 2006). Although the exact mechanism of aging is not known, one theory is related to oxidative stress and neuroinflammation. It has been proposed that neuroinflammation and oxidative stress is a major cause of aging process (Harper et al. 2004). Due to its high content of lipids and less antioxidant defense mechanisms, the brain is more vulnerable to oxidative stress (Floyd 1999). Oxidative stress products such as

Correspondence to: Selcen Aydın-Abidin, Department of Biophysics, Faculty of Medicine, Karadeniz Technical University, 61080 Trabzon, Turkey

E-mail: selcenabidin@yahoo.com superoxide and free radicals attack cellular components and damage functioning of cells (Pak et al. 2003). In addition, recent studies have shown that chronic inflammation is an important risk factor for aging and related diseases (Chung et al. 2006). Proinflammatory agents such as interleukin 1 beta (IL-1 $\beta$ ) and tumor necrosis factor alpha (TNF- $\alpha$ ) have been associated with cellular damage and neuronal loss (Heneka et al. 2015).

Brain derived neurotrophic factor (BDNF) is a small dimeric and a basic protein, which has essential regulatory roles in the central nervous system (Mattson et al. 2004). BDNF plays a crucial role in neuronal development, survival, maintenance and differentiation of neurons (McAllister et al. 1999). BDNF is important also in learning and memory and BDNF levels has been shown to be crucial for the synaptic function in hippocampus (Tyler et al. 2002) and various cortical regions (Abidin et al. 2006, 2019). It has been known that BDNF levels alter with increasing age (Webster et al. 2006). BDNF expression decreased in normal aging and also in Parkinson's disease, Alzheimer's disease and depression 
(Holsinger et al. 2000; Yasutake et al. 2006; Komulainen et al. 2008). Besides the major roles as neuromodulator, BDNF has been shown to have protective effects against oxidative stress (Valvassori et al. 2015; Abidin et al. 2018).

$7-8$, dihydroxyflavone (7,8-DHF) which is a potent agonist of Trk-B and mimics the effects of BDNF, has been identified in 2010 and found to cross blood brain barrier when injected systematically (Jang et al. 2010). Since its discovery, it has been demonstrated that 7,8-DHF has remedial effects on symptoms of neurological diseases and disorders in animal models including Parkinson's disease (Sconce et al. 2015), Alzheimer's disease (Zhang et al. 2014), amyotrophic lateral sclerosis (Korkmaz et al. 2014), Huntington's disease (Jiang et al. 2013), stroke (Wang et al. 2014), depression and Rett syndrome (Liu et al. 2010), and traumatic brain injury (Agrawal et al.2015). Andero and colleques showed that 7,8DHF application enhanced acquisition and extinction of fear in mice (Andero et al. 2011). It was observed that 7,8-DHF improved stress and aging associated cognitive impairment and plasticity in hippocampus (Andero et al. 2012; Zeng et al. 2012). These studies focused on hippocampus and the effect of 7,8-DHF on aging cortex is yet to be defined. Hence, in the present study, we investigated the potential effects of 7,8 -DHF on age-related changes in cortex. Also, in the search of a mechanistic correlate, we measured the neuroinflammation markers, synaptic protein levels and oxidative stress in young, old and DHF-treated old mice.

\section{Materials and Methods}

\section{Animals}

This study was approved by Karadeniz Technical University Animal Care and Ethics Committee. Mice used in the study were provided by Karadeniz Technical University Surgical Application and Research Center and all experimental procedures were performed in this center. A total of 27 male $\mathrm{C} 57 \mathrm{BL} / 6$ strain mice were divided into three groups as young control ( 5 months old, $n=10$ ), old control (18 months old, $n=10$ ) and old-DHF (18 months old, $n=7)$. 7,8-DHF (Sigma-Aldrich) was administered intraperitoneally to old-DHF group at a dose of $5 \mathrm{mg} / \mathrm{kg}$ in a vehicle of $17 \%$ dimethylsulfoxide in phosphate-buffered saline (DMSO) (Andero et al. 2011) for 3 weeks. 17\% DMSO alone was injected to young and old control groups for the same time. At the end of administration two different behavioral tests were performed to test cortical sensory-motor functions.

\section{Behavioral tests}

Behavioral tests were done at 10:00-12:00 o'clock. The experiments were recorded by using a video camera connected to a PC and analyzed offline. Hang wire and adhesive removal tests were conducted as these tests were related to somatosensory performance and closely related to the cortical function (Abe et al. 2009; Bouet et al. 2009).

\section{Hang wire}

Hang wire test was used to evaluate grip strength, balance and endurance in mice after chronic administration of 7,8-DHF to mice. The mouse was placed on a stretched wire with a $0.5 \mathrm{~cm}$ thick. The mouse had to carry its body weight with its forelimbs. A pillow was placed under $35 \mathrm{~cm}$ of the mice to prevent dangerous fall of the mice. Mice used their forelimbs to hang on the wire. The time until the mouse fell down was recorded. If the mouse didn't fall down in $120 \mathrm{~s}$, it was taken by the experimenter. The protocol for each mice consisted of two repeats both of which also consisted of 2 trials (in total 4 trials). There were $1 \mathrm{~h}$ intervals between two repeats and 2-3 min delay between two trials. The averages of 4 trials were calculated for each animal and used for statistical analysis ( $\mathrm{Li}$ et al. 2004; Abe et al. 2009). In hang wire test, holding time of the mice to wire was measured in seconds.

\section{Adhesive removal}

Adhesive removal test is another behavioral test that is used to assess sensorimotor deficits in mice. The healthy mouse feels the presence of a foreign material in its pow and then tries to get rid of it as earliest times. The delays in the first touching to the object and removal of object reflect sensorimotor deficits. A $3 \times 3 \mathrm{~mm}$ square, red adhesive tape strips were stuck to the front paws of the mice. The mouse tended to feel this foreign object and get rid of it. The time to touch one of the tapes with nose or mouth and the time to remove each tape were used for statistical comparisons. The tests were recorded with a maximum test time of $3 \mathrm{~min}$ (Bouet et al. 2009; Fleming et al. 2013). All scoring and analysis were confirmed by offline evaluation of video recordings. The test for each mouse was repeated for three times and there were 2-3 min intervals between repeats. In adhesive removal test too, the performances were given in seconds.

One day after the last behavioral test, the mice were sacrificed and the brains were rapidly removed. The cortical tissues were dissected and stored at $-80^{\circ} \mathrm{C}$ until the biochemical analysis.

\section{Enzyme-linked immunosorbent assay (ELISA)}

The cortical concentrations of Synaptophysin protein (SYP) and postsynaptic scaffolding protein postsynaptic density $95 \mathrm{kD}$ (PSD-95) and the levels of neuroinflammation markers IL- 6 and TNF- $\alpha$ were determined by ELISA. Left cortex of each mouse was processed for ELISA. Lysis buffer (1 mg/ 
tissue weight) contained: $137 \mathrm{mM} \mathrm{NaCl}, 2.7 \mathrm{mM} \mathrm{KCl}, 1.5$ $\mathrm{mM} \mathrm{KH}_{2} \mathrm{PO}_{4}, 7.7 \mathrm{mM} \mathrm{Na}_{2} \mathrm{HPO}_{4}, 1 \%$ Triton X-100, $5 \mathrm{mg} / \mathrm{ml}$ aprotinin, $5 \mathrm{mg} / \mathrm{ml}$ leupeptin $\mathrm{m}, \mathrm{pH}$ 7.4. Then the cortical tissue was homogenized by an ultrasonic cell disrupter (Sonics vibracell, Newtown, CT, USA). For $20 \mathrm{~min}$, the suspension was centrifuged at $20,000 \times g$. The supernatant was used for ELISA tests. TNF- $\alpha$, IL-6, SYP and PSD-95 levels were determined by using enzyme-linked immunosorbent assay (ELISA) kits (Elabscience, Catalog No: E-EL-M0049, E-ELM0044, E-EL-M1105 and USCN, Catalog No: SEG168Mu, respectively) according to the manufacturer's guide. Samples and standards absorbance were measured at $450 \mathrm{~nm}$ by using tunable microplate reader (VERSA max, Molecular Devices, Sunnyvale, CA, USA). Results were expressed as ng/ml.

\section{Tissue malondialdehyde (MDA) measurement}

A 50 to $60 \mathrm{mg}$ piece of right cortex was homogenized in $2 \mathrm{ml}$ ice-cold buffer $1.15 \% \mathrm{KCl}$ solution containing $0.5 \mathrm{ml} / 1$ Triton $\mathrm{X}-100$. MDA concentrations were measured from homogenates according to method by Mihara and Uchiyama (1978). Tetramethoxypropane was used as standard solution. MDA levels were expressed as $\mathrm{nmol} / \mathrm{ml}$ per gram of wet tissue.

\section{Measurements of tissue antioxidant enzyme activities}

Superoxide dismutase (SOD) and catalase (CAT) activities were measured from tissue samples of right cortex. Tissues were homogenized in $2 \mathrm{ml}$ ice-cold Tris- $\mathrm{HCl}$ buffer ( $50 \mathrm{mmol} / \mathrm{l}, \mathrm{pH}=7.4)$. SOD activities were measured by the method of Sun et al. (1988). This method essentially is based on reduction of nitroblue tetrazolium by xanthine/ xanthine oxidase system. SOD activity was given in U/mg protein. CAT activities were determined by the method of Goth (1991). This method utilizes $\mathrm{H}_{2} \mathrm{O}_{2}$ and ammonium molybdate stable complex. The yellow complex was meas- ured at $405 \mathrm{~nm}$. CAT activities were expressed as $\mathrm{kU} / \mathrm{mg}$ protein. For determination of protein concentrations, the tissue lysates were used. Bicinchoninic acid protein assay kit was used (Merck Millipore, Darmstadt, Germany) and results were expressed as $\mathrm{mg} / \mathrm{ml}$.

\section{Statistical analysis}

Data were presented as means \pm SEM. When data were normally distributed, significant differences between groups were analyzed by one-way ANOVA using GraphPad Prism software. For multiple comparisons Tukey's post hoc test was used. If data did not pass normality tests then non parametric Kruskal Wallis Test and Dunn's multiple comparison tests were used for comparison of group differences. $p<0.05$ was accepted as significant.

\section{Results}

\section{Effects of DHF on behavioral tests}

Analyzing the results of hang wire test, Kruskal-Wallis comparison revealed significant differences between groups. According to Dunn's multiple comparison post hoc test, the young mice hold the wire $(84.65 \pm 9.47 \mathrm{~s})$ significantly longer than old mice $(10.22 \pm 2.02 \mathrm{~s})(p<0.0001) .7,8$-DHF injected mice in old-DHF group $(43.40 \pm 7.3 \mathrm{~s})$ hold the wire significantly longer than old control mice $(p<0.05)$ (Fig, 1A).

In adhesive removal test, the contact time to the tape and first and second removal times were measured in seconds. One way ANOVA test of contact time revealed no significant differences between groups. Contact times to the tape were $6.1 \pm 0.85 \mathrm{~s}, 4.65 \pm 0.46 \mathrm{~s}, 4.57 \pm 0.75 \mathrm{~s}$ in young, old and old-DHF group, respectively. However, one way ANOVA test revealed significant differences in first and second removal
A

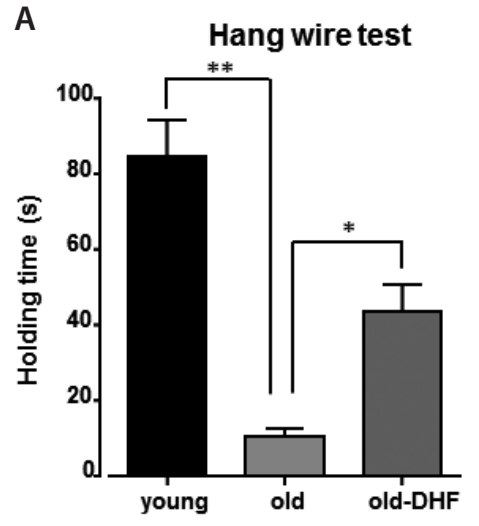

B

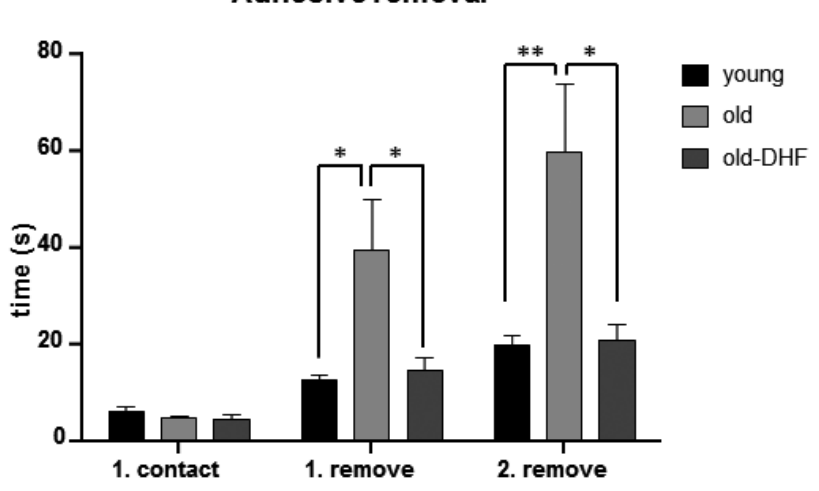

Figure 1. Effects of 7,8-DHF on behavioral experiments. A. Performance of old group was lower in hang wire test. Administration of 7,8-DHF improved the performance. B. Adhesive removal test. First removal and second removal of tape times were significantly higher in old group than young group. 3 weeks of application of 7,8-DHF considerably shortened the removal times ${ }^{*} p<0.05,{ }^{* *} p<0.005 ; n=10$ for young and old-DHF group, $n=7$ for old group). 
A

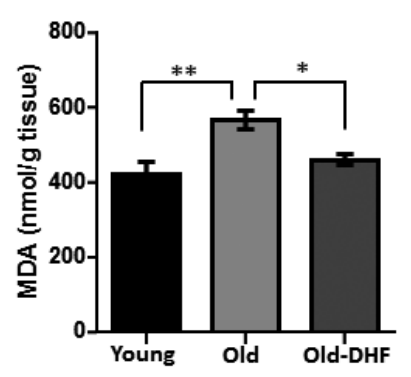

B

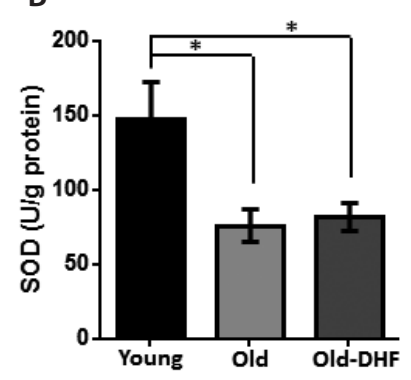

C

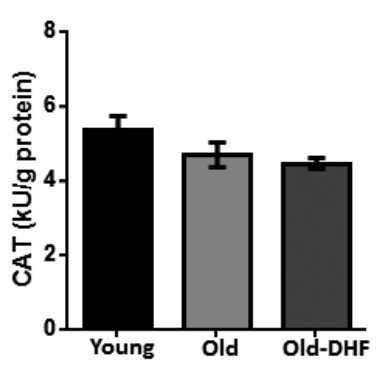

Figure 2. Effects of 7,8-DHF on oxidative stress. A. MDA level was found to be higher in old mice than young animals whereas chronic administration of 7,8-DHF reversed MDA level to young mice's level. B. SOD activity is less in old mice than young mice. Administration of DHF did not have any effect on SOD activity. C. There were no significant differences in CAT activities $\left({ }^{*} p<0.05,{ }^{* *} p<\right.$ $0.005 ; n=10$ for young and old-DHF group, $n=7$ for old group). of tape times between groups $(\mathrm{F}(2.48)=6.601, p=0.0029)$. Tukey's post hoc tests showed significant differences that first removal $(p<0.05)$ and second removal $(p<0.005)$ of tape times was significantly higher in old group than young group. In young group, first and second removal times were $12.80 \pm 0.97 \mathrm{~s}$ and $19.75 \pm 2.1 \mathrm{~s}$, respectively. In old group, removal times were $39.67 \pm 10.53 \mathrm{~s}$ and $59.78 \pm 14.35 \mathrm{~s}$. Administration of 7,8-DHF significantly improved the removal times $(14.46 \pm 2.79 \mathrm{~s}$ and $20.92 \pm 3.22 \mathrm{~s})(p<0.05)$. In old-DHF group the removal times decreased compared to old group (Fig. 1B).

\section{Effects of DHF on oxidative stress in aged mice}

To investigate the effects of 7,8-DHF on oxidative stress in aged mice we analyzed MDA level, SOD and CAT activity in cortex of mice brain. One way ANOVA revealed a significant differences in MDA levels between groups $(F(2.25)=9.215$; $p=0.001)$. As shown in Figure 2A, MDA level was found to be higher in old mice $(570.2 \pm 24.54 \mathrm{nmol} / \mathrm{g})$ than young animals $(423.9 \pm 31.08 \mathrm{nmol} / \mathrm{g})(p=0.0009$, according to Tukey's post hoc test); whereas chronic administration of
A

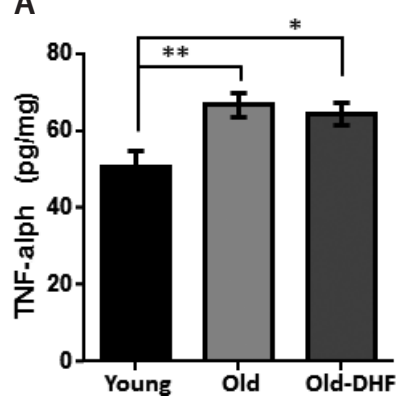

$B^{-}$

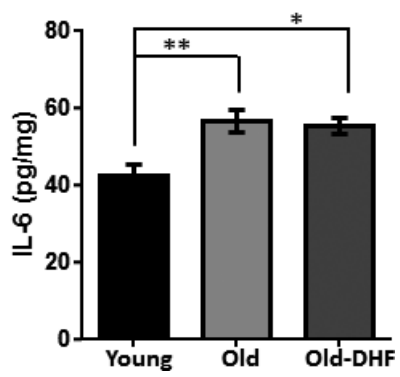

Figures 3. Effects of 7,8-DHF on neuroinflammation. TNF- $\alpha$ (A) and IL- $6 \beta$ (B) levels in the cortex of the old mice were significantly higher than those of the young mice but 7,8-DHF did not suppress IL- $6 \beta$ and TNF- $\alpha$ levels in the old mice $\left({ }^{*} p<0.05,{ }^{* *} p<0.005\right.$; $n=10$ for young and old-DHF group, $n=7$ for old group).
7,8-DHF reversed MDA level $(461.7 \pm 15.62 \mathrm{nmol} / \mathrm{g})$ to young mice's level ( $p=0.0199)$. SOD activity of different groups was shown in Figure 2B. There were significant differences in SOD activity between groups $(\mathrm{F}(2.24)=5.232$; $p=0.013)$. Aging decreased SOD activity in mice. SOD activity is lesser in old $(76.30 \pm 10.56 \mathrm{U} / \mathrm{g})$ than young mice $(147.8 \pm 24.81 \mathrm{U} / \mathrm{g})(p=0.0175$, Tukey's post hoc test). Administration of 7,8-DHF did not have any effect on SOD activity $(82.04 \pm 9.59 \mathrm{U} / \mathrm{g})$. CAT activities were $5.37 \pm 0.38 \mathrm{kU} / \mathrm{g}, 4.7 \pm 0.32 \mathrm{kU} / \mathrm{g}$ and $4.46 \pm 0.13 \mathrm{kU} / \mathrm{g}$ in young, old and old-DHF groups, respectively. There were no significant differences in CAT activities $(\mathrm{F}(2.23)=2.107$; $p=0.1444)$ (Fig. 2C).

\section{Effects of DHF on neuroinflammation in aged mice}

To investigate the effects of 7,8 -DHF on inflammatory responses, levels of interleukins (IL-6 $\beta$ ) and tumor necrosis factors (TNF- $\alpha$ ) were determined. IL-6 levels were 42.30 $\pm 3.26 \mathrm{pg} / \mathrm{mg}, 56.69 \pm 3.08 \mathrm{pg} / \mathrm{mg}$ and $55.51 \pm 2.09 \mathrm{pg} / \mathrm{mg}$ in young, old and old-DHF groups, respectively. According to one way ANOVA tests, IL- $6 \beta(\mathrm{F}(2.24)=7.354 ; p=0.0032)$ and TNF- $\alpha$ levels $(\mathrm{F}(2.24)=6.62 ; p=0.0051)$ are significantly different between groups. Figure 3 shows that IL-6 $\beta$ $(p=0.0047)$ levels in the cortex of the old mice were significantly higher than those of the young mice but 7,8-DHF did not suppress IL-6 $\beta$. Moreover TNF- $\alpha(p=0.0061)$ levels were also increased in old group $(66.82 \pm 3.01 \mathrm{pg} / \mathrm{mg})$ significantly compared to young group $(50.83 \pm 4.02 \mathrm{pg} / \mathrm{mg})$. In old-DHF group, TNF-a level $(64.54 \pm 2.9 \mathrm{pg} / \mathrm{mg})$ was not different compared to old group.

\section{Effects of DHF on synaptic proteins in aged mice}

The levels of synaptic proteins were decreased in old mice. One way ANOVA showed there is a significant differences in PSD-95 levels between groups $(\mathrm{F}(82.24)=4.363 ; p=0.0242)$. Tukey's test showed that PSD-95 levels were reduced in old mice $(4.2 \pm 0.27 \mathrm{ng} / \mathrm{mg})$ compared to young ones (5.61 
$\pm 0.47 \mathrm{ng} / \mathrm{mg})(p=0.0185)$. SYP level in old-DHF group was $4.99 \pm 0.11 \mathrm{ng} / \mathrm{mg}$ which is higher than in old group but it is not significant $(\mathrm{F}(2.24)=1.151 ; p=0.333)$. Besides, we did not find any significant differences in SYP levels between groups. SYP levels were $0.72 \pm 0.07 \mathrm{ng} / \mathrm{mg}, 0.60$ $\pm 0.046 \mathrm{ng} / \mathrm{mg}$ and $0.66 \pm 0.04 \mathrm{ng} / \mathrm{mg}$ in young, old and old-DHF groups, respectively. Although 7,8-DHF application increased the levels of synaptic protein, the differences were statistically insignificant (Fig. 4).

\section{Discussion}

Aging is a complex process in which both structural and functional changes occur in the brain (Hedden and Gabrieli 2004). In fact, aging is considered to be an important risk factor for various pathological conditions, including impaired behavioral performance, memory and cognition (Petersen 2004). Many studies suggest that the development of these pathologies may be affected by changes in expression of inflammatory markers (Rancán et al. 2017), increase in oxidative stress (Dröge and Schipper 2007) and reduction in synaptic plasticity (Bishop et al. 2010).

In this study we evaluated the beneficial effects of 7,8-DHF on age-induced changes in the cortex. We observed that aging worsened the performance of mice in behavioral tests which are basically related to cortical function (Seidler et al. 2010; Farias et al. 2019). During aging process, the expression of synaptic proteins decreases. The number of small synapse expressing PSD-95 (Ma et al. 2014; Xu et al. 2018) and the expression of SYP (Rancán et al. 2017; Ma et al. 2019) were reduced. In another study it has been shown that there was a decline in synaptophysin expression in old human subjects (Hatanpää et al. 1999). SYP and PSD-95 are markers of pre- and postsynapse, respectively. SYP, presynaptic vesicle protein, is a synaptic density marker and influences the release of neurotransmitters (Donovan et al. 2002) that induces the regeneration of additional neurons. PSD95 is the post synaptic marker which interacts with NMDA receptors to participate in the information storage process. PSD95 expression has an important role in regulating the potency of synaptic activity (Gardoni 2008). In agreement with these mentioned studies we also observed a decline in PSD-95 and SYP in elderly mice.

Another cause of synapse loss in old age may be neuroinflammation. Accordingly in this study, a significant increase in the amount of proinflammatory cytokines, TNF- $\alpha$ and IL- 6 was observed in the cortex of elderly mice. High amount of neuroinflammation could have hazardous effects on synaptic proteins and other proteins. The increased neuroinflammation in old animals has also been shown in other studies (Buchanan et al. 2008; Rancán et al. 2017; Zhao et al. 2018). In general, in the brain, neuronal inflammation
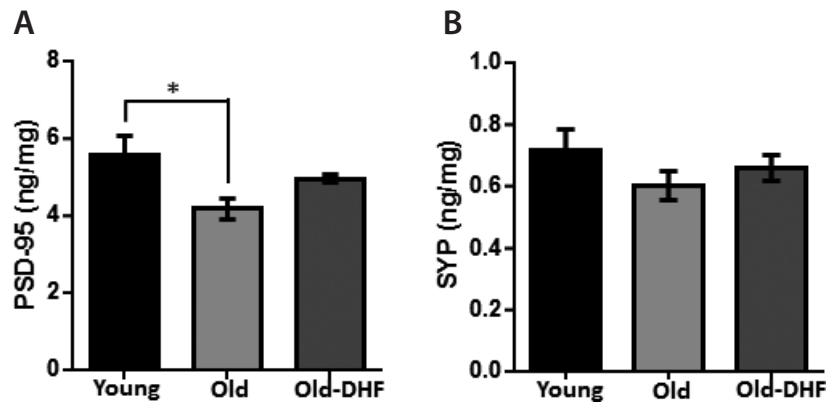

Figure 4. Effects of 7,8-DHF on Synaptic Proteins. A. PSD-95 levels were augmented in old group. However, administration of 7,8-DHF did not rescue PSD-95 level. B. There were no significant differences in synaptophysin level between groups $\left({ }^{*} p<\right.$ $0.05, n=10$ for young and old-DHF group, $n=7$ for old group). SYP, Synaptophysin; PSD-95, postsynaptic scaffolding protein postsynaptic density $95 \mathrm{kD}$.

and oxidative stress are related to each other (Durany et al. 1999; Floyd and Hensley 2002).

In this study, we have seen that there was an increment in lipid peroxidation in elderly mice. In old group of mice, MDA levels were significantly higher than younger ones. These findings of old mice were in line with previous studies (Montine et al. 2002; Petursdottir et al. 2007; Butterfield and Mattson 2020). Previously, the relation between cortical function and lipid peroxidation were reported in several studies. Elevated cortical lipid peroxidation levels were in correlation with evoked responses (Yaras et al. 2003; Yargıçoğlu et al. 2004). In line with these findings, in our study we observed a close relation between behavioral performances related to cortical functions and lipid peroxidation. Both are improved by 7,8-DHF application.

7,8-DHF is a small flavonoid that binds to Trk-B receptor and mimics BDNF. 7,8-DHF can efficiently pass through blood-brain barrier and enters the brain (Jang et al. 2010; Choi et al. 2010). This property of 7,8-DHF makes this molecule a therapeutic agent that can be used in place of BDNF. Here in our study, we have shown that chronic administration of 7,8-DHF to 18 months old mice reversed the impairment of behavioral performances in given tasks. In a previous study, chronic application of 7,8-DHF improved spatial learning and memory in old rats (Zeng et al. 2012). Similar to our findings, 7,8-DHF improved the behavioral outcomes in various animal models. It has been reported that 7,8-DHF rescued hippocampus-dependent memory deficits in Alzheimer's disease mice model (Devi and Ohno 2012). 7,8-DHF has been shown to improve motor function and prolongs survival in Huntington's disease (Jiang et al. 2013). In fact, 7,8-DHF has been shown to have a therapeutic effect when administered chronically in animal models such as Parkinson (Nie et al. 2019), Alzheimer's (Zhang et 
al. 2014), and depression models (Liu et al. 2013). These remedial action of 7,8-DHF in behavior performance might be attributed to its powerful antioxidant activity as evidenced by a significant decrease in MDA level in cortical areas in old mice. We suggest that 7,8-DHF improved the behavioral performances by its antioxidant action in our study. Although the antioxidant enzyme activities, SOD and CAT, were not affected by drug administration, the lipid peroxidation was reduced. In a recent study made with neuronal cells, 7,8-DHF protected high glucose-damaged cell against oxidative stress (Cho et al. 2019). Powerful antioxidant action of 7,8-DHF has been demonstrated in several studies against in scopolamine-induced oxidative stress (Chen et al. 2014), glutamate-induced toxicity (Chen et al. 2011), cerebral ischemia injury (Wang et al. 2014). All these studies are in line with our findings. In the present study CAT is not affected by age or 7,8-DHF application. The literature about the relation between aging and CAT is not in agreement. In the literature it has been reported that catalase activity is reduced by aged mice brain (Ahn et al. 2016). Another study suggested that catalase activity is increased in the cortex by age (Falone et al. 2012). However, there are also reports showing that catalase activity is not altered in various brain regions of the mice by age (Sohal et al. 1994; Hussain et al. 1995).

The anti-inflammatory action of 7,8-DHF has been shown in cells lines (Park et al. 2012, 2014; Choi et al. 2017). However, in this study we could not observe anti-inflammatory action of 7,8-DHF. It did not affect the levels of TNF- $\alpha$ and IL-6 markers in the cortical areas of old mice.

Contrary to studies showing that 7,8-DHF increases synaptic proteins in elderly rats (Zeng et al. 2012; Zhang et al. 2014), we could not observe a healing effect of 7,8-DHF on synaptic proteins in this study. It has been previously demonstrated that the decrease in activity of the BDNF-TrkB signaling pathway in elderly rats is associated with synaptic dysfunction and loss of synapse (Zeng et al. 2011). Thus, chronic administration of 7,8-DHF would be expected to improve synaptic proteins and increase the expressions. There are certain differences between the studies above and our experiments. Besides the differences in animal species, the application of the 7,8-DHF in our study is shorter. In this study, we applied 7,8-DHF for 3 weeks, which significantly less than in other studies in which the drug was administered for 4 months. From this point, we can argue that the duration of application is critical and 3 weeks of application were not sufficient to reverse the changes in inflammatory pathways and synaptic protein renewal.

\section{Conclusion}

In conclusion, these findings reflect that chronic application of small molecule 7,8-DHF improved age-related impair- ments of sensorimotor performances. In correlation, 7,8DHF also reduced the MDA levels which may be attributed to its antioxidant action.

\section{References}

Abe T, Kunz A, Shimamura M, Zhou P, Anrather J, Iadecola C (2009): The neuroprotective effect of prostaglandin E2 EP1 receptor inhibition has a wide therapeutic window, is sustained in time and is not sexually dimorphic. J. Cereb. Blood Flow. Metab. 29, 66-72 https://doi.org/10.1038/jcbfm.2008.88

Abidin İ, Köhler T, Weiler E, Zoidl G, Eysel UT, Lessmann V, Mittmann T (2006): Reduced presynaptic efficiency of excitatory synaptic transmission impairs LTP in the visual cortex of BDNF-heterozygous mice. Eur. J. Neurosci. 24, 3519-3531 https://doi.org/10.1111/j.1460-9568.2006.05242.x

Abidin İ, Aydın-Abidin S, Bodur A, İnce İ, Alver A (2018): Brainderived neurotropic factor (BDNF) heterozygous mice are more susceptible to synaptic protein loss in cerebral cortex during high fat diet. Arch. Physiol. Biochem. 124, 442-447 https://doi.org/10.1080/13813455.2017.1420666

Abidin İ, Aydın-Abidin S, Mittmann T (2019): Neuronal excitability and spontaneous synaptic transmission in the entorhinal cortex of BDNF heterozygous mice. Neurosci. Lett. 690, 69-75 https://doi.org/10.1016/j.neulet.2018.10.019

Agrawal R, Noble E, Tyagi E, Zhuang Y, Ying Z, Gomez-Pinilla F (2015): Flavonoid derivative 7,8-DHF attenuates TBI pathology via TrkB activation. Biochim. Biophys. Acta 1852, 862-872 https://doi.org/10.1016/j.bbadis.2015.01.018

Ahn JH, Chen BH, Shin BN, Lee TK, Cho JH, Kim IH, Park JH, Lee JC, et al (2016): Comparison of catalase immunoreactivity in the hippocampus between young, adult and aged mice and rats. Mol. Med. Rep. 14, 851-856 https://doi.org/10.3892/mmr.2016.5300

Andero R, Heldt SA, Ye K, Liu X, Armario A, Ressler KJ (2011): Effect of 7,8-dihydroxyflavone, a small-molecule TrkB agonist, on emotional learning. Am. J. Psychiatry 168, 163-172 https://doi.org/10.1176/appi.ajp.2010.10030326

Andero R, Daviu N, Escorihuela RM, Nadal R, Armario A (2012): 7,8-dihydroxyflavone, a TrkB receptor agonist, blocks longterm spatial memory impairment caused by immobilization stress in rats. Hippocampus 22, 399-408 https://doi.org/10.1002/hipo.20906

Bao Q, Pan J, Qi H, Wang L, Qian H, Jiang F, Shao Z, Xu F, Tao Z, Ma Q, et al. (2014): Aging and age-related diseases - From endocrine therapy to target therapy. Mol. Cell Endocrinol. 394, 115-118 https://doi.org/10.1016/j.mce.2014.07.005

Bishop NA, Lu T, Yankner BA (2010): Neural mechanisms of ageing and cognitive decline. Nature 464, 529-535 https://doi.org/10.1038/nature08983

Bouet V, Boulouard M, Toutain J, Divoux D, Bernaudin M, Schumann-Bard P, Freret T (2009): The adhesive removal test: A sensitive method to assess sensorimotor deficits in mice. Nat. Protoc. 4, 1560-1564 
https://doi.org/10.1038/nprot.2009.125

Buchanan JB, Sparkman NL, Chen J, Johnson RW (2008): Cognitive and neuroinflammatory consequences of mild repeated stress are exacerbated in aged mice. Psychoneuroendocrinology 33, 755-765 https://doi.org/10.1016/j.psyneuen.2008.02.013

Butterfield DA, Mattson MP (2020): Apolipoprotein E and oxidative stress in brain with relevance to Alzheimer's disease. Neurobiol. Dis. 138, 104795 https://doi.org/10.1016/j.nbd.2020.104795

Chen C, Li X, Zhang S, Tu Y, Wang Y, Sun H (2014): 7,8-Dihydroxyflavone ameliorates Scopolamine induced Alzheimer-like pathologic dysfunction. Rejuvenation Res. 17, 246-254 https://doi.org/10.1089/rej.2013.1519

Chen J, Chua KW, Chua CC, Yu H, Pei A, Chua BHL, Hamdy RC, Xu X, Liu CF (2011): Antioxidant activity of 7,8-dihydroxyflavone provides neuroprotection against glutamate-induced toxicity. Neurosci. Lett. 499, 181-185 https://doi.org/10.1016/j.neulet.2011.05.054

Cho SJ, Kang KA, Piao MJ, Ryu YS, Fernando PDSM, Zhen AX, Hyun YJ, Ahn MJ, Kang HK, Hyun JW (2019): 7,8-Dihydroxyflavone protects high glucose-damaged neuronal cells against oxidative stress. Biomol. Ther. 27, 85-91 https://doi.org/10.4062/biomolther.2018.202

Choi DC, Maguschak KA, Ye K, Jang SW, Myers KM, Ressler KJ (2010): Prelimbic cortical BDNF is required for memory of learned fear but not extinction or innate fear. PNAS USA 107, 2675-2680

https://doi.org/10.1073/pnas.0909359107

Choi JW, Lee J, Park YI (2017): 7,8-Dihydroxyflavone attenuates TNF- $\alpha$-induced skin aging in Hs68 human dermal fibroblast cells via down-regulation of the MAPKs/Akt signaling pathways. Biomed. Pharmacother. 95, 1580-1587 https://doi.org/10.1016/j.biopha.2017.09.098

Chung HY, Sung B, Jung KJ, Zou Y, Yu BP (2006): The molecular inflammatory process in aging. Antiox. Redox Signal. 8, 572-581 https://doi.org/10.1089/ars.2006.8.572

Devi L, Ohno M (2012): 7,8-dihydroxyflavone, a small-molecule TrkB agonist, reverses memory deficits and BACE1 elevation in a mouse model of Alzheimer's disease. Neuropsychopharmacology 37, 434-444 https://doi.org/10.1038/npp.2011.191

Donovan SL, Mamounas LA, Andrews AM, Blue ME, McCasland JS (2002): GAP-43 is critical for normal development of the serotonergic innervation in forebrain. J. Neurosci. 22, 3543-3552 https://doi.org/10.1523/JNEUROSCI.22-09-03543.2002

Dröge W, Schipper HM (2007): Oxidative stress and aberrant signaling in aging and cognitive decline. Aging Cell 6, 361-370 https://doi.org/10.1111/j.1474-9726.2007.00294.x

Durany N, Münch G, Michel T, Riederer P (1999): Investigations on oxidative stress and therapeutical implications in dementia. Eur. Arch. Psychiatry Clin. Neurosci. 249, 68-73 https://doi.org/10.1007/PL00014177

Falone S, D'Alessandro A, Mirabilio A, Petruccelli G, Cacchio M, Di Ilio C, Di Loreto S, Amicarelli F. (2012): Long term running biphasically improves methylglyoxal-related metabolism, redox homeostasis and neurotrophic support within adult mouse brain cortex. PLoS One 7, e31401 https://doi.org/10.1371/journal.pone.0031401

Farias Quipildor GE, Mao K, Hu Z, Novaj A, Cui MH, Gulinello M, Branch CA, Gubbi S, Patel K, Moellering DR et al. (2019): Central IGF-1 protects against features of cognitive and sensorimotor decline with aging in male mice. GeroScience 41, 185-208 https://doi.org/10.1007/s11357-019-00065-3

Fleming SM, Ekhator OR, Ghisays V (2013): Assessment of sensorimotor function in mouse models of Parkinsons disease. J. Vis. Exp. 76, 1-7 https://doi.org/10.3791/50303

Floyd RA, Hensley K (2002): Oxidative stress in brain aging: Implications for therapeutics of neurodegenerative diseases. Neurobiol. Aging 23, 795-807 https://doi.org/10.1016/S0197-4580(02)00019-2

Floyd RA (1999): Antioxidants, oxidative stress, and degenerative neurological disorders. Proc. Soc. Exp. Biol. Med. 222, 236-245 https://doi.org/10.1046/j.1525-1373.1999.d01-140.x

Gardoni F (2008): MAGUK proteins: New targets for pharmacological intervention in the glutamatergic synapse. Eur. J. Pharmacol. 585, 147-152 https://doi.org/10.1016/j.ejphar.2008.01.048

Goth L (1991): A simple method for determination of serum catalase activity and revision of reference range. Clin. Chim. Acta 196, 143-151 https://doi.org/10.1016/0009-8981(91)90067-M

Harper ME, Bevilacqua L, Hagopian K, Weindruch R, Ramsey JJ (2004): Ageing, oxidative stress, and mitochondrial uncoupling. Acta Physiol. Scand. 182, 321-331 https://doi.org/10.1111/j.1365-201X.2004.01370.x

Hatanpää K, Isaacs KR, Shirao T, Brady DR, Rapoport SI (1999): Loss of proteins regulating synaptic plasticity in normal aging of the human brain and in Alzheimer disease. J. Neuropathol. Exp. Neurol. 58, 637-643 https://doi.org/10.1097/00005072-199906000-00008

Hedden T, Gabrieli JD (2004): Insights into the ageing mind: A view from cognitive neuroscience. Nat. Rev. Neurosci. 5, 87-96

https://doi.org/10.1038/nrn1323

Heneka MT, Carson MJ, El Khoury J, Gary E, Brosseron F, Feinstein DL, Jacobs AH, Wyss-Coray T, Vitorica J, Ransohoff RM, et al. (2015): Neuroinflammation in Alzheimer's disease. Lancet Neurol. 14, 388-405 https://doi.org/10.1016/S1474-4422(15)70016-5

Holsinger RMD, Schnarr J, Henry P, Castelo VT, Fahnestock M (2000): Quantitation of BDNF mRNA in human parietal cortex by competitive reverse transcription-polymerase chain reaction: Decreased levels in Alzheimer's disease. Mol. Brain Res. 76, 347-354 https://doi.org/10.1016/S0169-328X(00)00023-1

Hussain S, Slikker W Jr, Ali SF (1995): Age-related changes in antioxidant enzymes, superoxide dismutase, catalase, glutathione peroxidase and glutathione in different regions of mouse brain. Int. J. Dev. Neurosci. 13, 811-817 https://doi.org/10.1016/0736-5748(95)00071-2

Jang SW, Liu X, Yepes M, Shepherd KR, Miller GW, Liu Y, Wilson WD, Xiao G, Blanchi B, Sun YE et al. (2010): A selective TrkB agonist with potent neurotrophic activities by 7,8-dihydroxyflavone. PNAS USA 107, 2687-2692 
https://doi.org/10.1073/pnas.0913572107

Jiang M, Peng Q, Liu X, Jin J, Hou Z, Zhang J, Mori S, Ross CA, Ye K, Duan W (2013): Small-molecule TrKB receptor agonists improve motor function and extend survival in a mouse model of Huntington's disease. Hum. Mol. Genet. 22, 2462-2470 https://doi.org/10.1093/hmg/ddt098

Keller JN (2006): Age-related neuropathology, cognitive decline, and Alzheimer's disease. Ageing Res. Rev. 5, 1-13 https://doi.org/10.1016/j.arr.2005.06.002

Komulainen P, Pedersen M, Hänninen T, Bruunsgaard H, Lakka TA, Kivipelto M, Hassinen M, Rauramaa TH, Pedersen BK, Rauramaa R (2008): BDNF is a novel marker of cognitive function in ageing women: The DR's EXTRA Study. Neurobiol. Learn Mem. 90, 596-603 https://doi.org/10.1016/j.nlm.2008.07.014

Korkmaz OT, Aytan N, Carreras I, Choi JK, Kowall NW, Jenkins BG, Dedeoglu A (2014): 7,8-Dihydroxyflavone improves motor performance and enhances lower motor neuronal survival in a mouse model of amyotrophic lateral sclerosis. Neurosci. Lett. 566, 286-291 https://doi.org/10.1016/j.neulet.2014.02.058

Li X, Blizzard KK, Zeng Z, DeVries AC, Hurn PD, McCullough LD (2014): Chronic behavioral testing after focal ischemia in the mouse: Functional recovery and the effects of gender. Exp. Neurol. 187, 94-104 https://doi.org/10.1016/j.expneurol.2004.01.004

Lin MT, Beal MF (2006): Mitochondrial dysfunction and oxidative stress in neurodegenerative diseases. Nature 443, 787-795 https://doi.org/10.1038/nature05292

Liu X, Chan CB, Jang SW, Pradoldej S, Huang J, He K, Phun LH, France S, Xiao G, Jia Y et al. (2010): A synthetic 7,8-dihydroxyflavone derivative promotes neurogenesis and exhibits potent antidepressant effect. J. Med. Chem. 53, 8274-8286 https://doi.org/10.1021/jm101206p

Liu X, Qi Q, Xiao G, Li J, Hongbo LR, Keqiang Y (2013): O-Methylated metabolite of 7,8-dihydroxyflavone activates TrkB receptor and displays antidepressant activity. Pharmacology 91, 185-200 https://doi.org/10.1159/000346920

Ma J, Zhang Z, Kang L, Geng D, Wang Y, Wang M, Cui H (2014): Repetitive transcranial magnetic stimulation (rTMS) influences spatial cognition and modulates hippocampal structural synaptic plasticity in aging mice. Exp. Gerontol. 58, 256-268 https://doi.org/10.1016/j.exger.2014.08.011

Ma Q, Geng Y, Wang H, Han B, Wang Y (2019): High frequency repetitive transcranial magnetic stimulation alleviates cognitive impairment and modulates hippocampal synaptic structural plasticity in aged mice. Front Aging Neurosci. 11, 235 https://doi.org/10.3389/fnagi.2019.00235

Mattson MP, Maudsley S, Martin B (2004): BDNF and 5-HT: A dynamic duo in age-related neuronal plasticity and neurodegenerative disorders. Trends Neurosci. 27, 589-594 https://doi.org/10.1016/j.tins.2004.08.001

McAllister AK, Katz LC, Lo DC (1999): Neurotrophins and synaptic plasticity. Annu. Rev. Neurosci. 22, 295-318 https://doi.org/10.1146/annurev.neuro.22.1.295

Mihara M, Uchiyama M (1978): Determination of malonaldehyde precursor in tissues by thiobarbituric acid test. Anal. Biochem. 86, 271-278 https://doi.org/10.1016/0003-2697(78)90342-1

Montine TJ, Neely MD, Quinn JF, Beal MF, Markesbery WR, Roberts LJ, Morrow JD (2002): Lipid peroxidation in aging brain and Alzheimer's disease. Free Radic. Biol. Med. 33, 620-626 https://doi.org/10.1016/S0891-5849(02)00807-9

Nie S, Ma K, Sun M, Lee M, Tan Y, Chen G, Zhang Z, Zhang Z, Cao X (2019): 7,8-Dihydroxyflavone protects nigrostriatal dopaminergic neurons from rotenone-induced neurotoxicity in rodents. Parkinson's Dis. 2019, 9193534 https://doi.org/10.1155/2019/9193534

Pak JW, Herbst A, Bua E, Gokey N, McKenzie D, Aiken JM (2003): Mitochondrial DNA mutations as a fundamental mechanism in physiological declines associated with aging. Aging Cell $2,1-7$ https://doi.org/10.1046/j.1474-9728.2003.00034.x

Park HY, Kim GY, Hyun JW, Hwang HJ, Kim ND, Kim BW, Choi YH (2012): 7,8-Dihydroxyflavone exhibits anti-inflammatory properties by downregulating the NF- $\mathrm{kB}$ and MAPK signaling pathways in lipopolysaccharide-treated RAW264.7 cells. Int. J. Mol. Med. 29, 1146-1152

Park HY, Park C, Hwang HJ, Kim BW, Kim GY, Kim CM, Kim ND, Choi YH (2014): 7,8-Dihydroxyflavone attenuates the release of pro-inflammatory mediators and cytokines in lipopolysaccharide-stimulated BV2 microglial cells through the suppression of the NF- $\mathrm{BB}$ and MAPK signaling pathways. Int. J. Mol. Med. 33, 1027-1034 https://doi.org/10.3892/ijmm.2014.1652

Petersen RC (2004): Mild cognitive impairment as a diagnostic entity. J. Intern. Med. 256, 183-194 https://doi.org/10.1111/j.1365-2796.2004.01388.x

Petursdottir AL, Farr SA, Morley JE, Banks WA, Skuladottir GV (2007): Lipid peroxidation in brain during aging in the senescence-accelerated mouse (SAM). Neurobiol. Aging 28, 1170-1178

https://doi.org/10.1016/j.neurobiolaging.2006.05.033

Rancán L, Paredes SD, García I, Muñoz P, García C, López de Hontanar G, de la Fuente M, Vara E, Tresguerres JAF (2017): Protective effect of xanthohumol against age-related brain damage. J. Nutr. Biochem. 49, 133-140 https://doi.org/10.1016/j.jnutbio.2017.07.011

Sconce MD, Churchill MJ, Moore C, Meshul CK (2015): Intervention with 7,8-dihydroxyflavone blocks further striatal terminal loss and restores motor deficits in a progressive mouse model of Parkinson's disease. Neuroscience 290, 454-471 https://doi.org/10.1016/j.neuroscience.2014.12.080

Seidler RD, Bernard JA, Burutolu TB, Fling BW, Gordon MT, Gwin JT, Kwak Y, Lipps DB (2010): Motor control and aging: Links to age-related brain structural, functional, and biochemical effects. Neurosci. Biobehav. Rev. 34, 721-733 https://doi.org/10.1016/j.neubiorev.2009.10.005

Sohal RS, Ku HH, Agarwal S, Forster MJ, Lal H. (1994): Oxidative damage, mitochondrial oxidant generation and antioxidant defenses during aging and in response to food restriction in the mouse. Mech. Ageing Dev. 74, 121-133 https://doi.org/10.1016/0047-6374(94)90104-X

Sun Y, Oberley LW, Li Y (1988): A simple method for clinical assay of superoxide dismutase. Clin. Chem. 34, 497-500 https://doi.org/10.1093/clinchem/34.3.497 
Tyler WJ, Alonso M, Bramham CR, Pozzo-Miller LD (2002): From acquisition to consoliadation: on the role of BDNF signaling in hippocampal-dependent learning. Learn. Mem. 9, 224-237 https://doi.org/10.1101/lm.51202

Valvassori SS, Arent CO, Steckert AV, Varela RB, Jornada LK, Tonin PT, Budni J, Mariot E, Kapczinski F, Quevedo J (2015): Intracerebral administration of BDNF protects rat brain against oxidative stress induced by ouabain in an animal model of mania. Mol. Neurobiol. 52, 353-362 https://doi.org/10.1007/s12035-014-8873-8

Wang B, Wu N, Liang F, Zhang S, Ni W, Cao Y, Xia D, Xi H (2014): 7,8-dihydroxyflavone, a small-molecule tropomyosin-related kinase B (TrkB) agonist, attenuates cerebral ischemia and reperfusion injury in rats. J. Mol. Histol. 45, 129-140 https://doi.org/10.1007/s10735-013-9539-y

Webster MJ, Herman MM, Kleinman JE, Shannon Weickert C (2006): BDNF and trkB mRNA expression in the hippocampus and temporal cortex during the human lifespan. Gene Expr. Patterns 6, 941-951 https://doi.org/10.1016/j.modgep.2006.03.009

Xu B, Sun A, He Y, Qian F, Xi S, Long D (2018): Loss of thin spines and small synapses contributes to defective hippocampal function in aged mice. Neurobiol. Aging 71, 91-104 https://doi.org/10.1016/j.neurobiolaging.2018.07.010

Yaras N, Yargicoglu P, Agar A, Gumuslu S, Abidin I, Ozdemir S (2003): Effect of immobilization and cold stress on visual evoked potentials. Int. J. Neurosci. 113, 1055-1067 https://doi.org/10.1080/00207450390203708

Yargiçoğlu P, Yaraş N, Ağar A, Gümüşlü S, Abidin I, Bilmen S (2004): Effects of N-nitro L-arginine methyl ester (L-NAME), a potent nitric oxide synthase inhibitor, on visual evoked potentials of rats exposed to different experimental stress models. Acta Physiol. Scand. 180, 307-316 https://doi.org/10.1111/j.0001-6772.2003.01254.x

Yasutake C, Kuroda K, Yanagawa T, Okamura T, Yoneda H (2006): Serum BDNF, TNF- $\alpha$ and IL- $1 \beta$ levels in dementia patients: Comparison between Alzheimer's disease and vascular dementia. Eur. Arch. Psychiatry Clin. Neurosci. 256, 402-406 https://doi.org/10.1007/s00406-006-0652-8

Zeng Y, Lv F, Li L, Yu H, Dong M, Fu Q (2012): 7,8-dihydroxyflavone rescues spatial memory and synaptic plasticity in cognitively impaired aged rats. J. Neurochem. 122, 800-811 https://doi.org/10.1111/j.1471-4159.2012.07830.x

Zeng Y, Tan M, Kohyama J, Sneddon M, Watson JB, Sun YE, Xie CW (2011): Epigenetic enhancement of BDNF signaling rescues synaptic plasticity in aging. J. Neurosci. 31, 17800-17810 https://doi.org/10.1523/JNEUROSCI.3878-11.2011

Zhang Z, Liu X, Schroeder JP, Chan CB, Song M, Yu SP, Weinshenker D, Ye K (2014): 7,8-dihydroxyflavone prevents synaptic loss and memory deficits in a mouse model of Alzheimer's disease. Neuropsychopharmacology 39, 638-650 https://doi.org/10.1038/npp.2013.243

Zhao YF, Qiong-Zhang, Zhang JF, Lou ZY, Zu HB, Wang ZG, Zeng WC, Kai-Yao, Xiao BG (2018): The synergy of aging and LPS exposure in a mouse model of Parkinson's disease. Aging Dis. 9, 785-797 https://doi.org/10.14336/AD.2017.1028

Received: April 27, 2020

Final version accepted: June 17, 2020 